\section{$Y-12$}

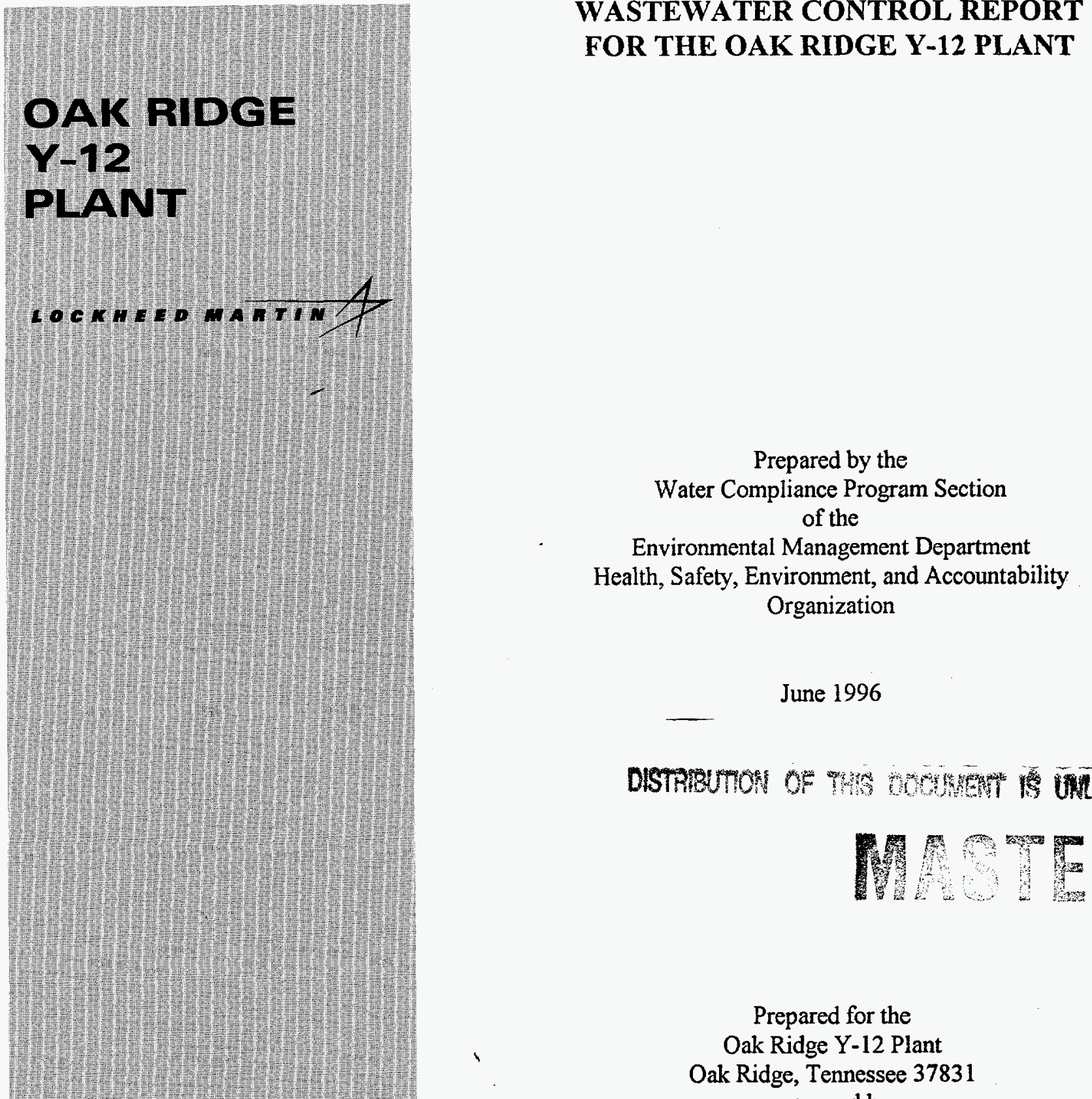

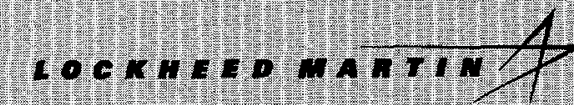

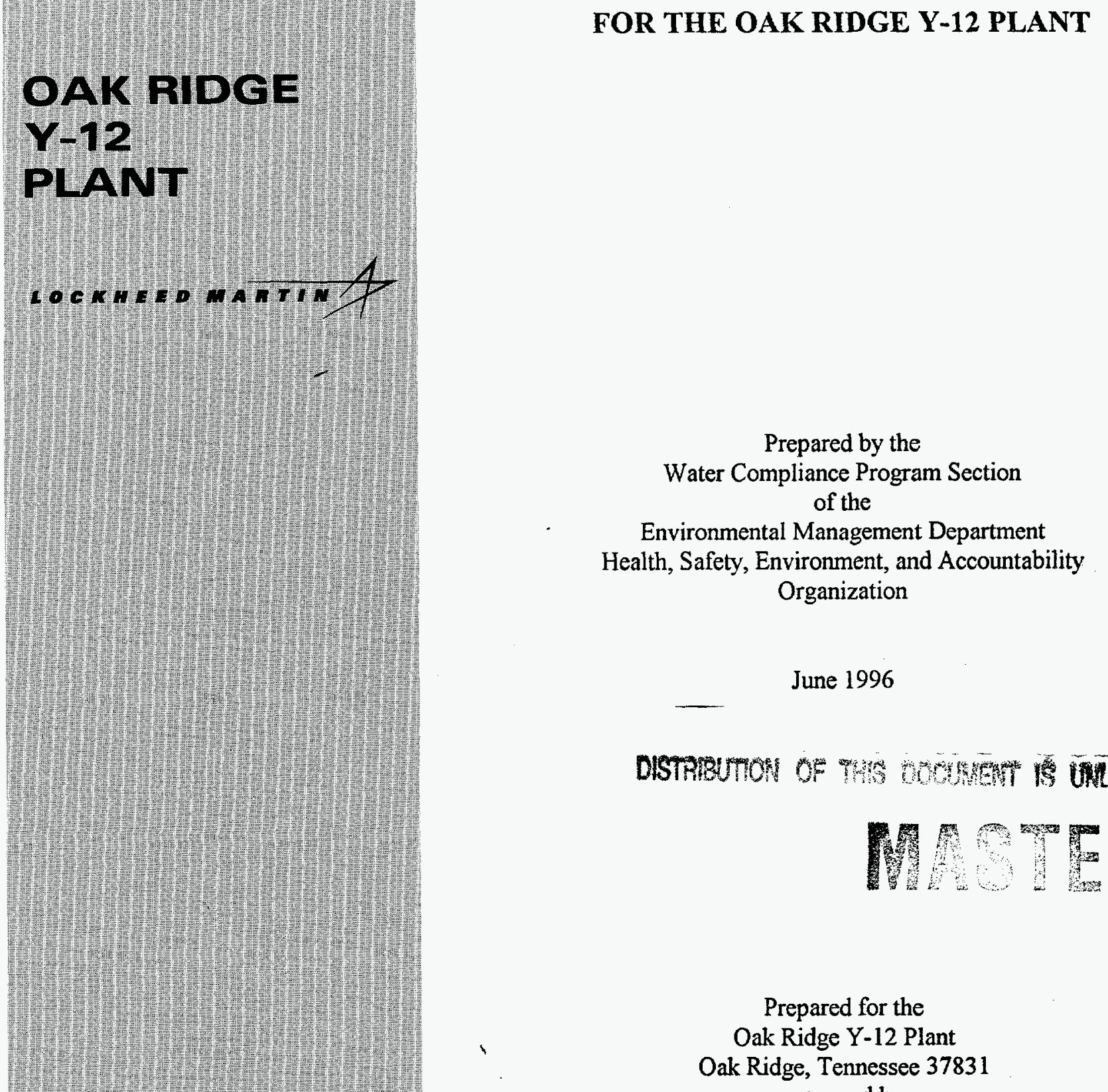

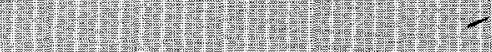

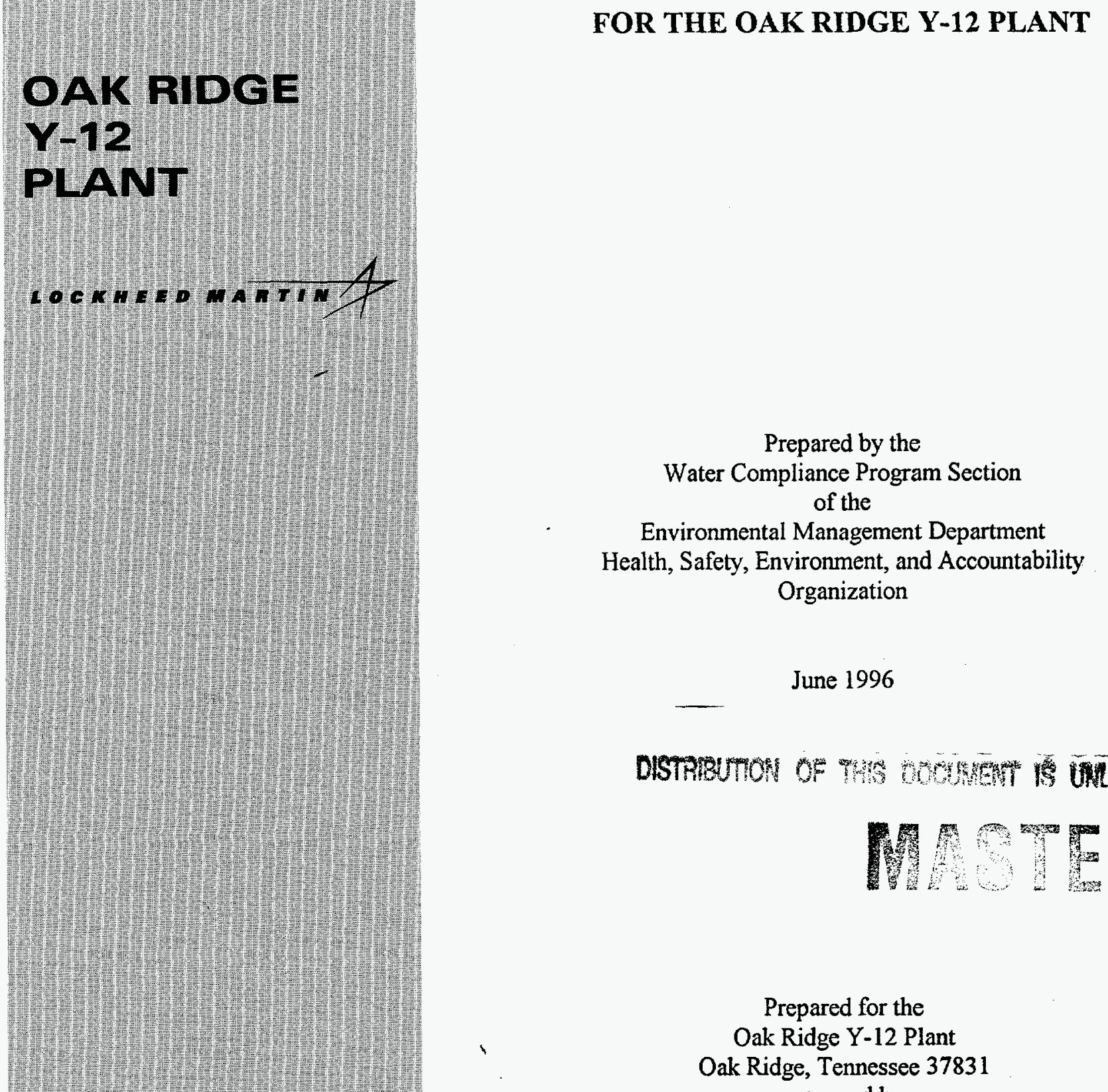

\section{(a)}
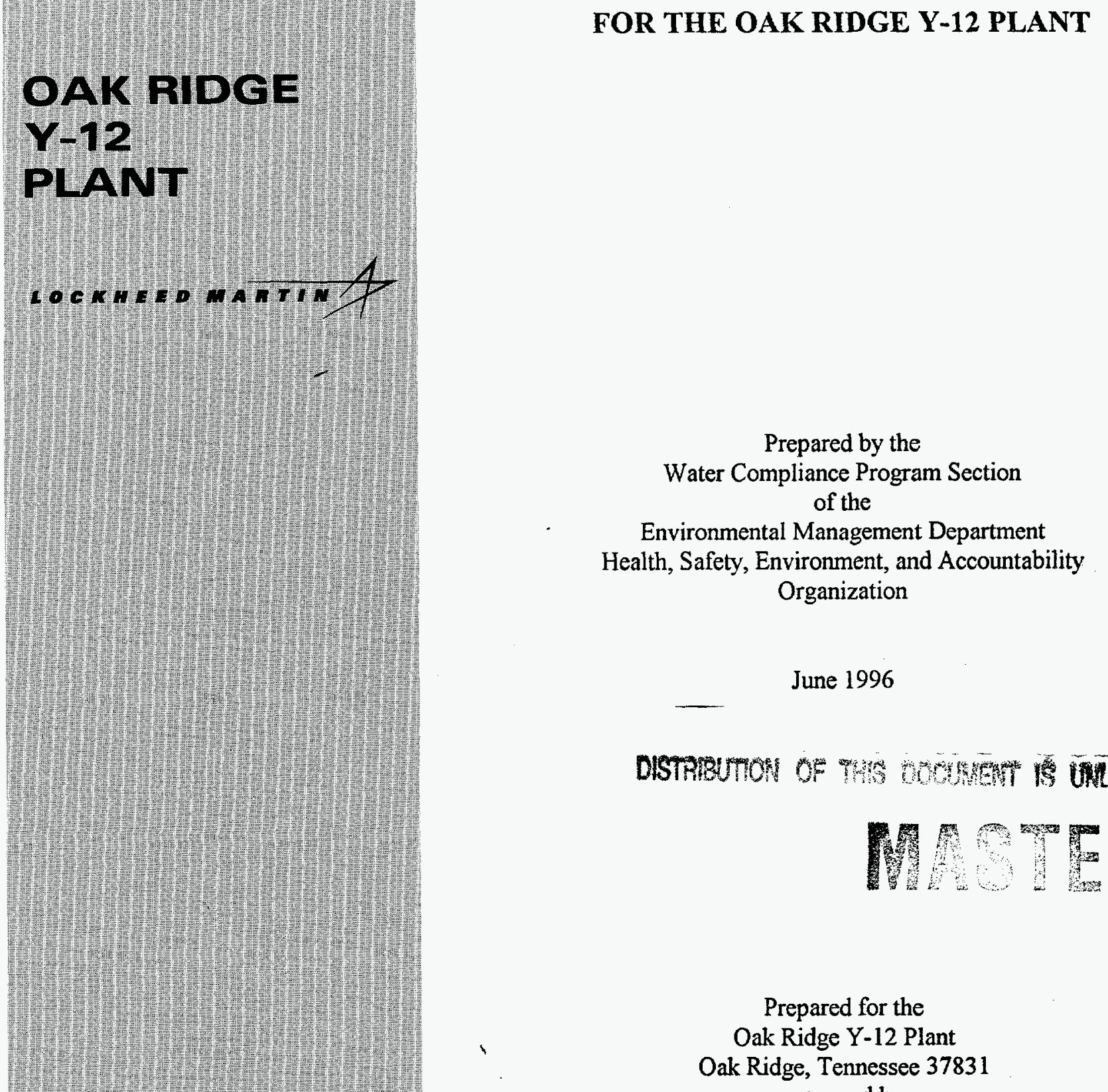

itit:

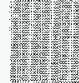

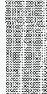
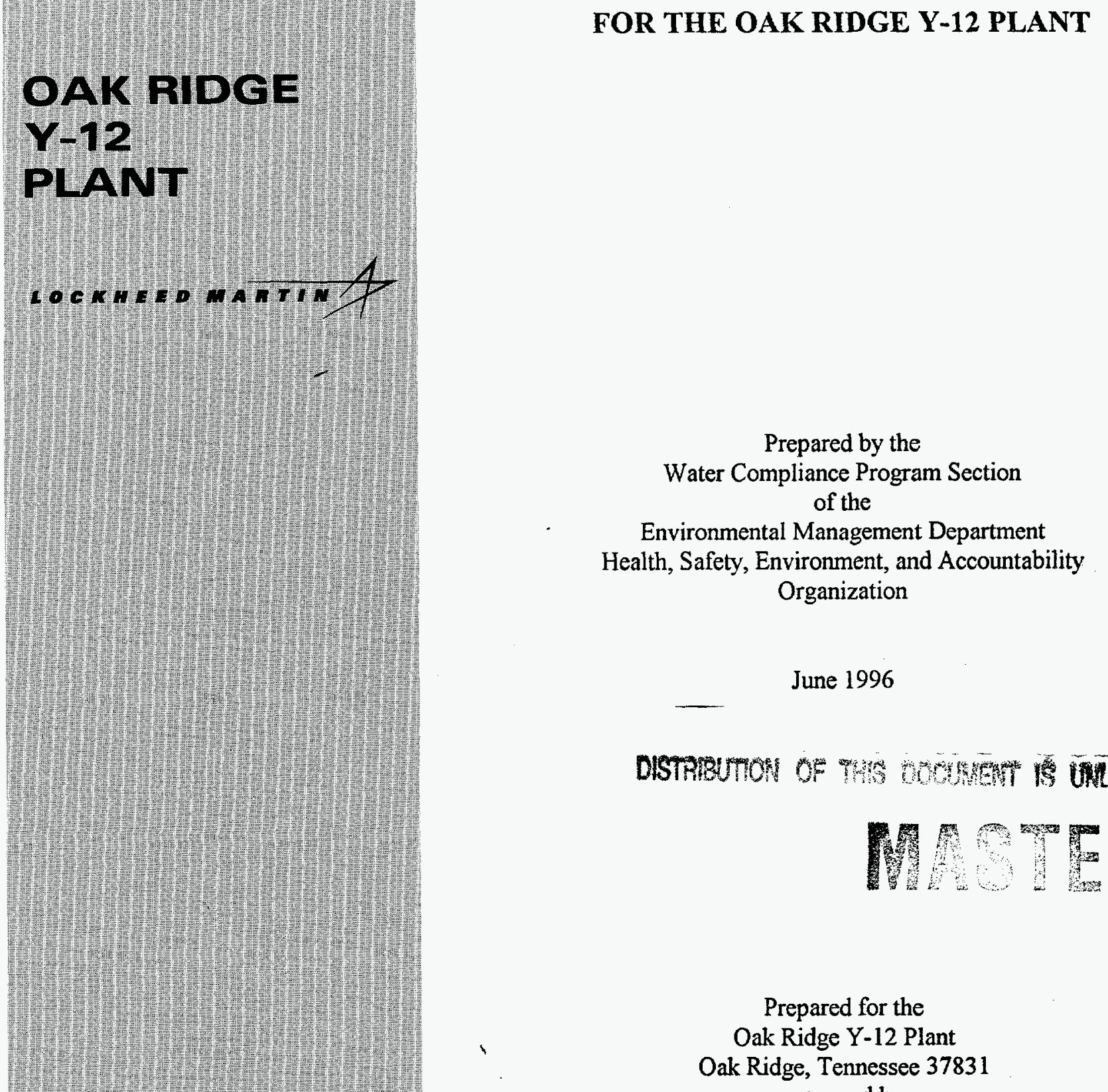

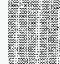

\section{(1)}

\section{(3) \\ (i)}

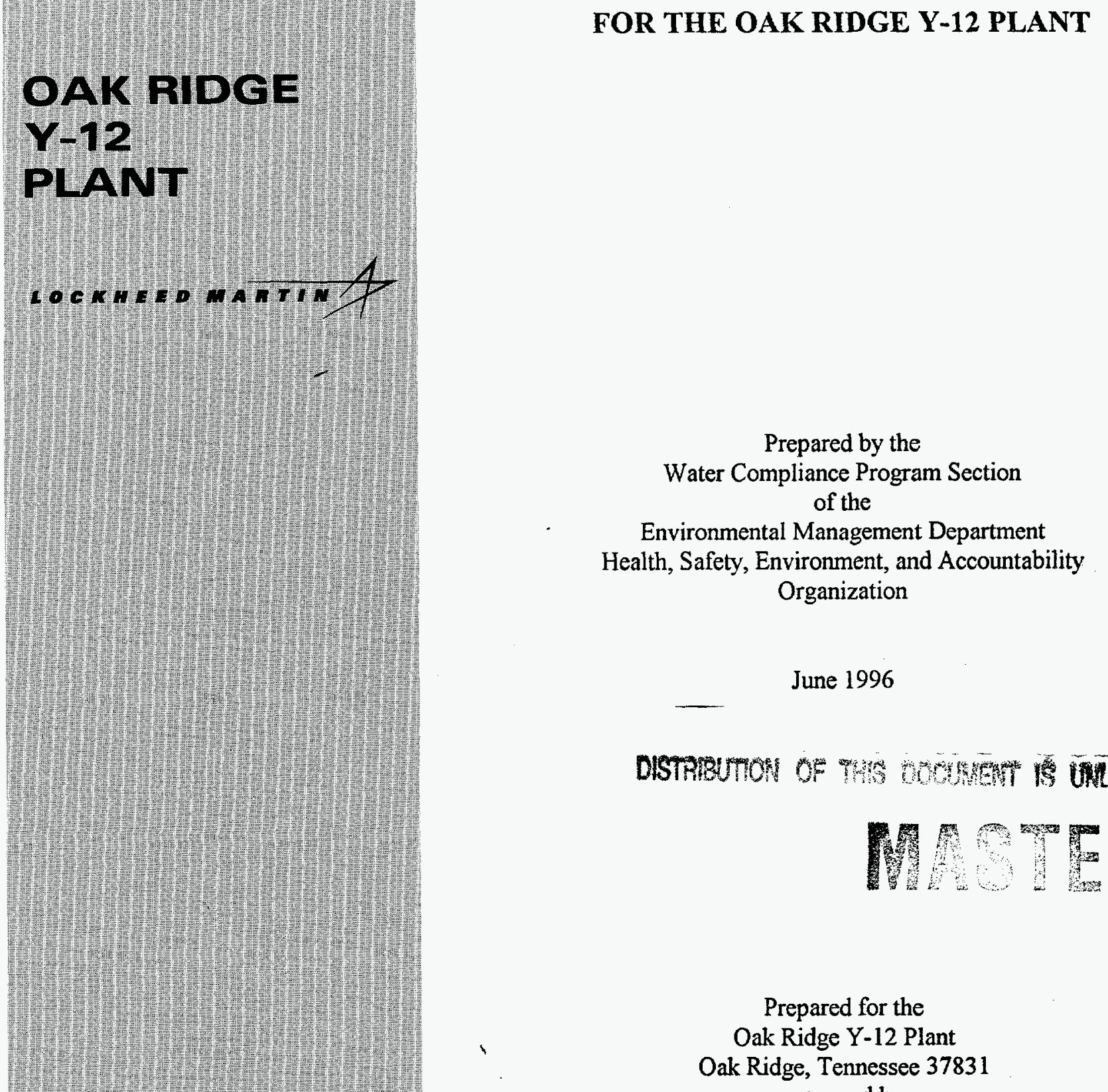

\section{is}
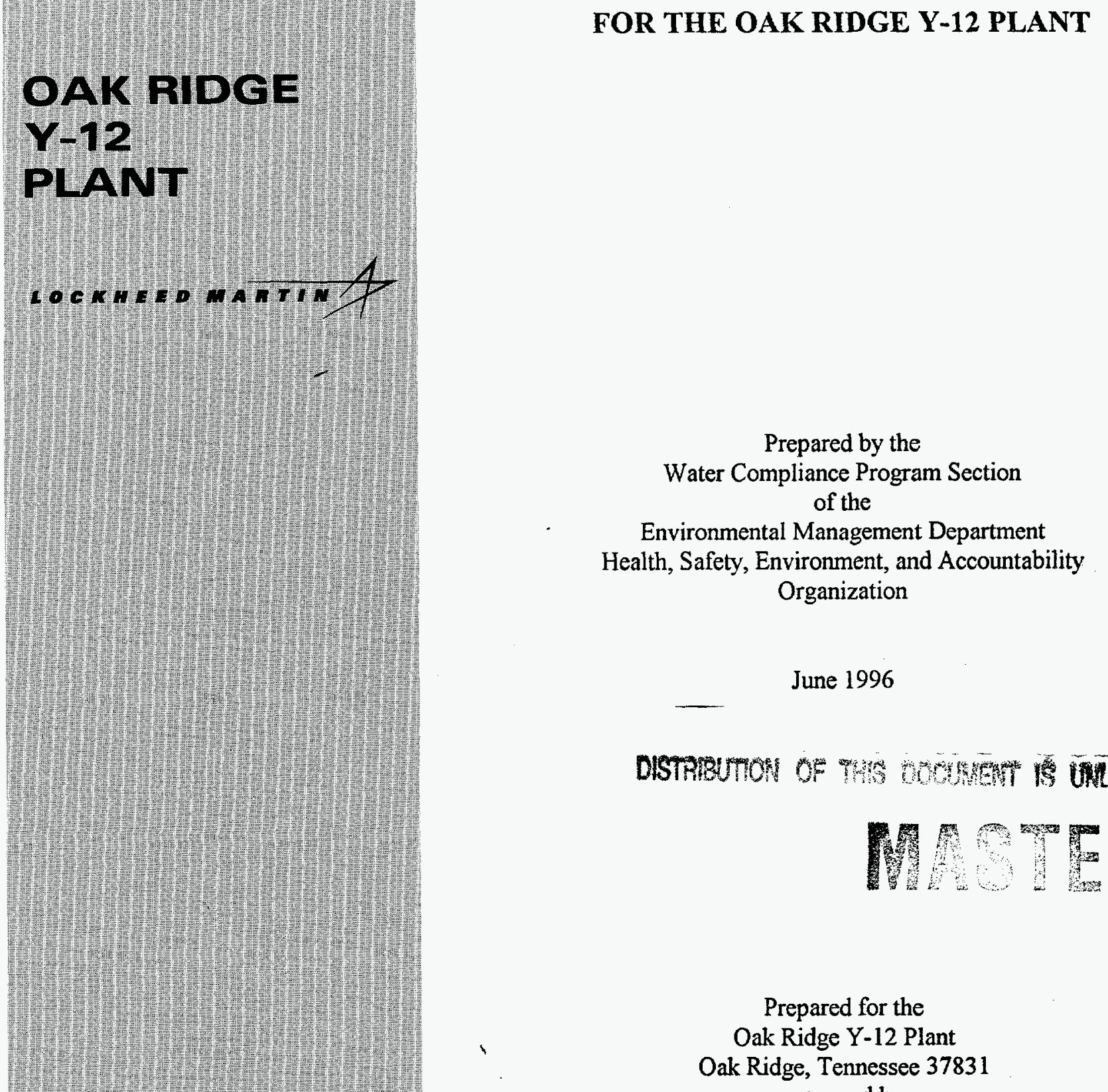

\section{V.:}

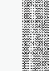
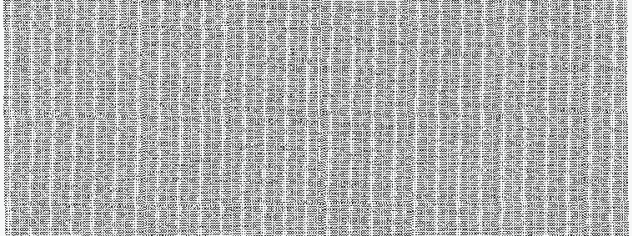

25: : : : : : :

20. W

MANAGED BY LOCKHEED MARTIN ENERGY SYSTEMS, INC. FOR THE UNITED STATES DEPARTMENT OF ENERGY

UCN-13672 (28 6-95)

\section{WASTEWATER CONTROL REPORT FOR THE OAK RIDGE Y-12 PLANT}

Prepared by the

$$
\text { of the }
$$

ealth, Safety, Environment, and Accountability

Organization

June 1996

managed by

LOCKHEED MARTIN ENERGY SYSTEMS, INC.

for the

U.S. DEPARTMENT OF ENERGY

under contract

DE-AC05-84OR21400 


\section{DISCLAIMER}

This report was prepared as an account of work sponsored by an agency of the United States Government. Neither the United States Government nor any agency thereof, nor any of their employees, makes any warranty, express or implied, or assumes any legal liability or responsibility for the accuracy, completeness, or usefulness of any information, apparatus, product, or process disclosed, or represents that its use would not infringe privately owned rights. Reference herein to any specific commercial product, process, or service by trade name, trademark, manufacturer, or otherwise, does not necessarily constitute or imply its endorsement, recommendation, or favoring by the United States Government or any agency thereof. The views and opinions of authors expressed herein do not necessarily state or reflect those of the United States Government or any agency thereof. 


\title{
WASTEWATER CONTROL REPORT FOR THE OAK RIDGE Y-12 PLANT
}

\author{
Prepared by the \\ Water Compliance Program Section \\ of the \\ Environmental Management Department \\ Health, Safety, Environment, and Accountability \\ Organization
}

June 1996

\author{
Prepared for the \\ Oak Ridge Y-12 Plant \\ Oak Ridge, Tennessee 37831 \\ managed by \\ LOCKHEED MARTIN ENERGY SYSTEMS, INC. \\ for the \\ U.S. DEPARTMENT OF ENERGY \\ under contract \\ DE-AC05-84OR21400
}




\section{DISClAMMER}

Portions of this document may be illegible in electronic image products. Images are produced from the best available original document. 


\section{Table of Contents}

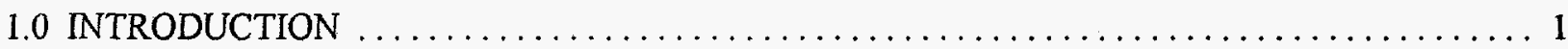

1.1 Central Pollution Control Facility $(\mathrm{CPCF}) \ldots \ldots \ldots \ldots \ldots \ldots \ldots \ldots \ldots \ldots \ldots \ldots$

1.2 West End Treatment Facility (WETF) and West Tank Farm (WTF) $\ldots \ldots \ldots \ldots \ldots \ldots, 1$

1.3 Groundwater Treatment Facility (GWTF) and Liquid Storage Facility (LSF) $\ldots \ldots \ldots \ldots 1$

1.4 Steam Plant Wastewater Treatment Facility (SPWTF) $\ldots \ldots \ldots \ldots \ldots \ldots \ldots \ldots \ldots 2$

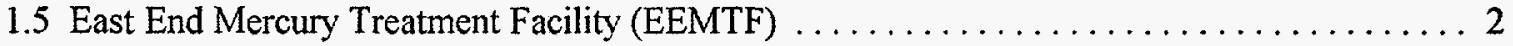

1.6 Central Mercury Treatment Facility (CMTF) $\ldots \ldots \ldots \ldots \ldots \ldots \ldots \ldots \ldots \ldots . \ldots \ldots$

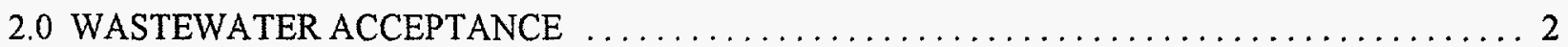

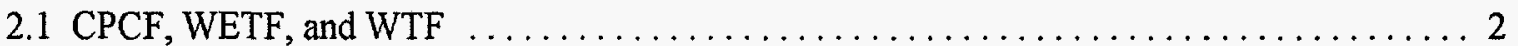

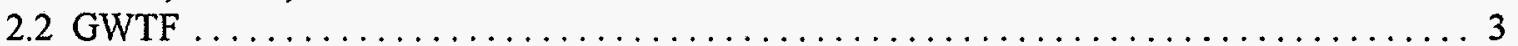

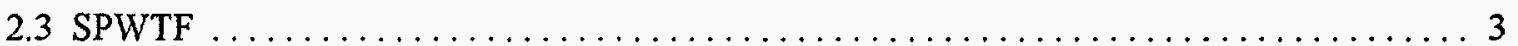

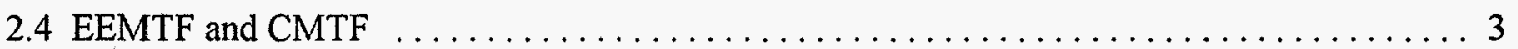

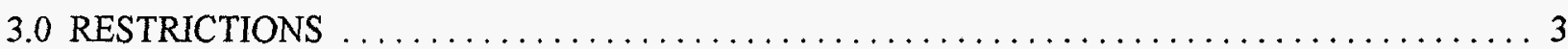

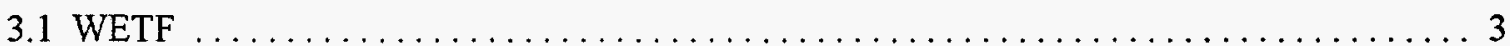

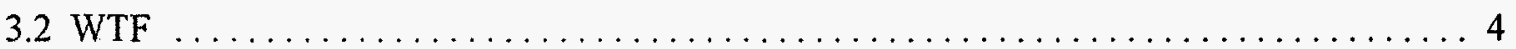

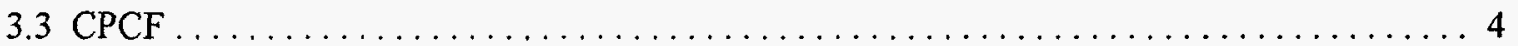

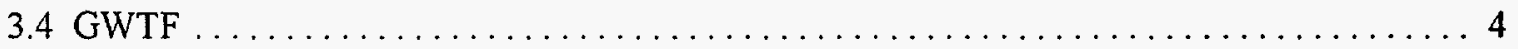

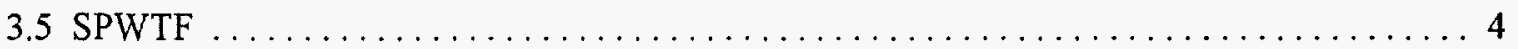

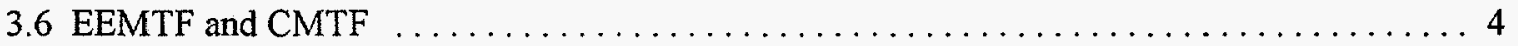

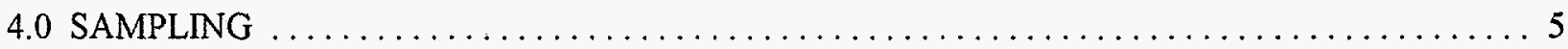

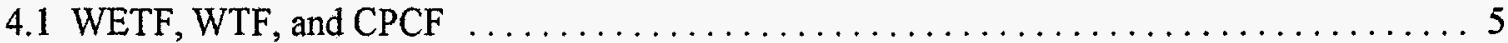

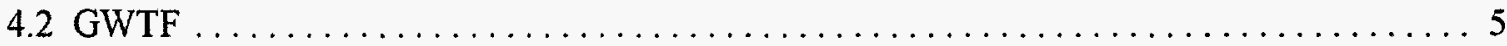

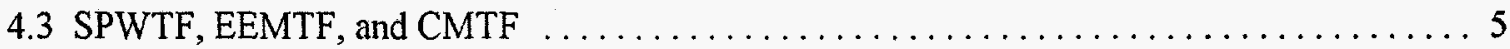

5.0 DATA REVIEW AND TREATMENT FACILITY ASSIGNMENT $\ldots \ldots \ldots \ldots \ldots \ldots \ldots \ldots 6$

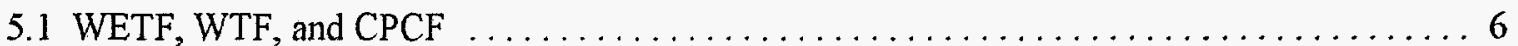

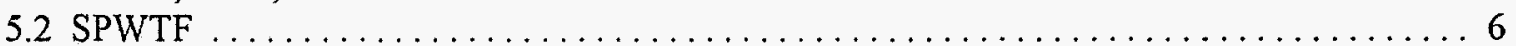

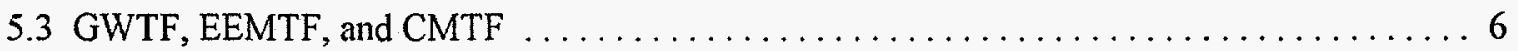

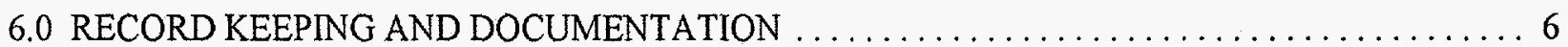

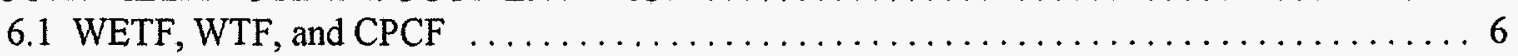

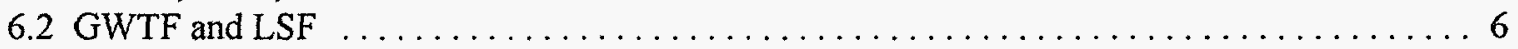

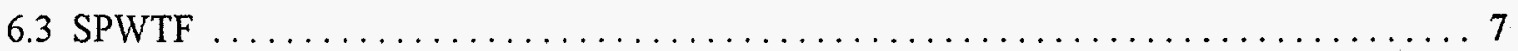

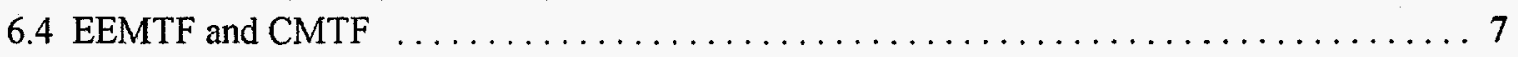

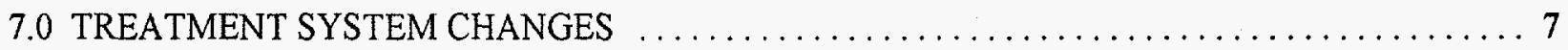

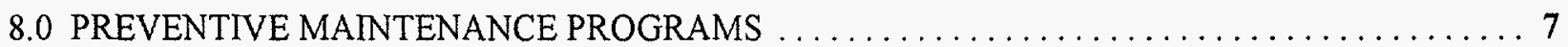

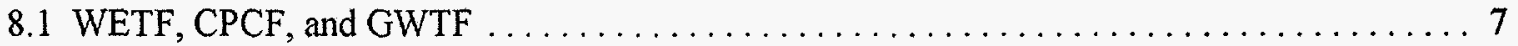

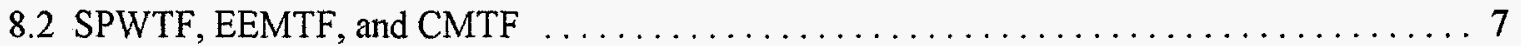

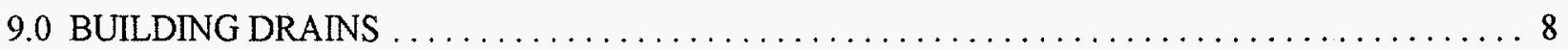




\section{WASTEWATER CONTROL REPORT \\ FOR THE OAK RIDGE Y-12 PLANT}

\subsection{INTRODUCTION}

The 1995 National Pollutant Discharge Elimination System (NPDES) permit for the Y-12 Plant (Part III-F, page 41) requires the preparation of a report to describe procedures and criteria used in operating on-site treatment systems to maintain compliance with the NPDES permit. This report has been prepared to fulfill this requirement. Five wastewater treatment systems are currently in operation at the Y-12 Plant; they are operated by personnel in the Waste Management and Facilities Management Organizations.

\subsection{Central Pollution Control Facility (CPCF)}

The CPCF is operated by the Waste Management Organization staff and designed to treat a variety of industrial wastewater generated throughout the Y-12 Plant. Wastewater treated at CPCF may be dilute wastewater (also called mop water); concentrated wastewater; and dilute, metal-plating-shop rinse water. Dilute wastewater is typically generated by cleaning and rinsing operations performed at various Y-12 Plant production facilities and will usually have higher organic content and lower metal content than the concentrated wastewater. Concentrated wastewater is typically derived from chemical processes and is usually not diluted before arriving at CPCF. This wastewater usually has a high level of dissolved metal, including various compounds of soluble uranium, and high acidity or alkalinity levels. Since no component at CPCF removes nitrates, effluents from nitrate receipts are shipped to the West Tank Farm (WTF) (see Section 1.2) for nitrate destruction. Both mop water and concentrated wastewater are transported to CPCF by 5,000-gallon tanker trucks and 300-gallon tuff tanks. Dilute metal-plating-shop rinse water is received at CPCF through a pipeline from the Y-12 Plating Shop. This wastewater is typically clean compared with mop water and concentrated wastewater. The plating rinse water wastestream is characteristically contaminated with trace amounts of heavy metals that are effectively removed in the treatment process. Effluent flow from CPCF is estimated at approximately 7,500 gallons a day and is monitored at NPDES Outfall 501 before being discharged to East Fork Poplar Creek (EFPC).

\subsection{West End Treatment Facility (WETF) and WTF}

The WETF and WTF are operated by the Waste Management Organization staff and designed to treat nitrate-bearing wastewater from Y-12 Plant production operations. Typical waste streams treated by the WETF and WTF include acid nitrate wastewater, biodenitrification plant effluent, caustic solutions from metal-cleaning operations, decontaminating solutions, sodium nitrate solutions from electropolishing operations, nitrate-containing mop water, laboratory wastewater from analytical work, concentrated wastewater from washing/pickling components with nitric acid, and dilute plating wastewater containing nitrates. Wastewater is delivered in 5,000-gallon tanker trucks; 300-gallon tuff tanks; and various small containers such as drums, carboys, and bottles. Effluent flow from the WETF ranges from 16,000 to 36,000 gallons a day and is monitored at NPDES Outfall 502 before being discharged to EFPC.

\subsection{Groundwater Treatment Facility (GWTF) and Liquid Storage Facility (LSF)}

The GWTF treats contaminated groundwater seeps from the Bear Creek Burial Grounds after they are collected at the LSF; the Waste Management Organization staff operates both facilities. The water may be contaminated with various volatile and nonvolatile organic compounds. The oil phase of the collected seep 
water is contaminated with polychlorinated biphenyls (PCBs). The collected seep water is processed through an oil/water separator at the LSF to remove the oil from the water. The water is transported to the GWTF where it is treated to remove volatile and nonvolatile organic compounds and iron. The GWTF also provides interim treatment of seep water from the K-25 SW31 Spring Project. Wastewater is transported to the GWTF by 5,000-gallon tanker trucks. The GWTF discharges approximately 2.5 million gallons of effluent a year from the LSF, and approximately 1.5 million gallons of effluent a year from the K-25 Site; it is monitored at NPDES Outfall 512 before being discharged to EFPC.

\subsection{Steam Plant Wastewater Treatment Facility (SPWTF)}

The Facilities Management Organization staff operates the SPWTF and provides treatment for an estimated 65 million gallons a year of acid discharges from the Y-12 Plant coal yard and steam plant operations. The facility treats demineralizer regeneration wastewater, sodium- and acid-softener regeneration wastewater, boiler blowdown, wet ash decant, and coal pile runoff. Coal pile runoff typically contains suspended coal fines, low pH, metals (e.g., iron, copper, aluminum, manganese), and a high sulfate concentration. Coal pile runoff is routed to a 373,000-gallon equalization basin from a concrete-lined collection ditch surrounding the coal pile. Boiler blowdown and demineralizer wastewater enter the SPWTF at the 124,000-gallon equalization basin. Currently, effluent is not discharged to EFPC; it is discharged to the sanitary sewer. The NPDES monitoring point (Outfall 503) is inactive.

\subsection{East End Mercury Treatment Facility (EEMTF)}

The EEMTF is operated by the Waste Management Organization staff and provides treatment for an estimated 30 gallons a minute of mercury-contaminated groundwater which naturally flows into the basement of Building 9201-2 from groundwater springs. The basement floor and the groundwater below are contaminated with mercury from historical spills that occurred in the building. The groundwater is directly piped to the treatment system which removes the mercury. Effluent from the EEMTF is monitored at NPDES Outfall 550 before being discharged to EFPC.

\subsection{Central Mercury Treatment Facility (CMTF)}

The CMTF is a facility under construction at the CPCF and is designed to remove mercury from groundwater from basement sumps in Buildings 9201-4, 9201-5, and 9204-4. This groundwater, which is contaminated with mercury from historical spills that occurred in these buildings, will be either directly piped to the CMTF or transported in tuff tanks. Effluent from the CMTF will be monitored at the future NPDES Outfall 551 before being discharged to EFPC. Operation of the CMTF is planned for late 1996.

\subsection{WASTEWATER ACCEPTANCE}

\subsection{CPCF, WETF, and WTF}

The Waste Management Organization Waste Treatment Coordinator (WTC) determines wastewater acceptance at the CPCF, WETF, and WTF in accordance with waste evaluation criteria detailed in plant procedures. The WTC makes acceptance decisions based on review of laboratory analyses, assigns wastewater to appropriate treatment facilities, field checks wastewater containers, and processes requests for disposal and shipment reports for transportation and disposal of wastewater. The WTC coordinates disposal of wastewater by interfacing between generators and Waste Management personnel. The WTC also serves as 
a wastewater treatment facility representative for the receipt and treatment of wastewater from sites other than the Y-12 Plant. The WTC maintains records of all waste receipts at the treatment facilities, including pertinent analytical data.

\subsection{GWTF}

Although the Waste Management Organization staff operates the GWTF, the waste evaluation criteria used at the WETF and CPCF do not apply to the GWTF operations. The wastewater treated at the GWTF comes from contaminated groundwater seeps in the Bear Creek Burial Grounds. This water is collected at the LSF and transported to the GWTF for treatment. On an interim basis, seep water from the K-25 SW31 Spring Project is transported to the GWTF accompanied by hazardous waste manifests. As detailed in a memorandum of understanding between K-25 Site personnel and the GWTF Facility Engineer, K-25 Site personnel perform periodic sampling of the wastewater and provide the laboratory reports to the GWTF Facility Engineer. Manifests and laboratory reports are available from the GWTF Facility Engineer.

\subsection{SPWTF}

Due to the nature of operations at the SPWTF, wastewater is not evaluated prior to acceptance for treatment. Physical barriers prevent the introduction of unauthorized wastestreams (i.e., mop water, domestic wastewater). Demineralizer regeneration, sodium- and acid-softener regeneration, boiler blowdown, and wet ash decant wastewater are all generated and transported to SPWTF in closed systems. Although boiler blowdown wastewater is pumped from a sump, the sump is closed; and no floor drains are routed to the sump. Similarly, for wet ash decant, no other drains are routed to the wet ash sump. Coal pile runoff is directed to the SPWTF via a trench surrounding the coal pile. No waste or process lines are routed overhead within the trench boundary.

\subsection{EEMTF and CMTF}

Due to the nature of operations at the EEMTF and CMTF, wastewater is not evaluated prior to acceptance for treatment. Groundwater that flows into the building sumps is directly piped to the treatment systems, except groundwater from Building 9204-4 which will be collected and transported to CMTF in 300-gallon tuff tanks.

\subsection{RESTRICTIONS}

\subsection{WETF}

The following are prohibited at the WETF: (1) waste containing less than 50 percent water; (2) U-, P-, or K-listed waste; (3) wastewater that contains PCBs at $50 \mathrm{ppm}$ or greater (wastewater that contains PCBs greater than 0.1 but less than $50 \mathrm{ppm}$ may be accepted on a case-by-case basis); (4) wastewater derived from waste containing PCBs of $50 \mathrm{ppm}$ or greater; and (5) wastewater containing excessive oil and grease (greater than one inch of oil on any wastewater in containers). Receiving limits are also placed on cyanide, mercury, cadmium, chromium, nickel, and lithium. The WTC must approve deviations from these guidelines. Specific waste evaluation criteria for the WETF are detailed in Procedure Y50-41-WT-09.21. 


\subsection{WTF}

The following are prohibited at the WTF: (1) waste containing less than 50 percent water; (2) U-, P-, or K-listed waste; (3) wastewater that contains PCBs at $50 \mathrm{ppm}$ or greater (wastewater that contains PCBs greater than 0.1 but less than $50 \mathrm{ppm}$ may be accepted on a case-by-case basis); (4) wastewater derived from waste containing PCBs of $50 \mathrm{ppm}$ or greater; and (5) wastewater containing excessive oil and grease (greater than one inch of oil on any wastewater in containers). Receiving limits are also placed on cyanide, mercury, cadmium, chromium, copper, lead, lithium, nickel, and silver. The WTC must approve deviations from these guidelines. Specific waste evaluation criteria are detailed in Procedure Y50-41-WT-03.21.

\subsection{CPCF}

The following are prohibited at the CPCF: (1) waste containing less than 50 percent water; (2) U-, P-, or $\mathrm{K}$-listed waste; (3) wastewater that contains PCBs at $50 \mathrm{ppm}$ or greater (wastewater that contains PCBs greater than 0.1 but less than $50 \mathrm{ppm}$ may be accepted on a case-by-case basis); (4) wastewater derived from waste containing PCBs of $50 \mathrm{ppm}$ or greater; and (5) uranium-235 concentrations no greater than those specified by Nuclear Criticality Safety personnel. Specific waste evaluation criteria are detailed in Procedure Y50-41-WP-08.02. The Facility Engineer and WTC must approve deviations from these criteria.

\subsection{GWTF}

Wastewater from significant sources other than contaminated groundwater from the Bear Creek Burial Grounds, the LSF, and seep water from the K-25 SW31 Spring Project will not be accepted for treatment without prior approval of Tennessee Department of Environment and Conservation (TDEC), Division of Water Pollution Control, personnel; however, wastewater not specified in the procedures may be temporarily accepted on a case-by-case basis, with memorandums of understanding written to specify acceptance criteria, analytical parameters, and sampling frequency. Memorandums of understandings will be used when procedure revisions are impractical.

\subsection{SPWTF}

Wastewater from sources other than coal yard runoff and steam plant operations are not accepted for treatment. The physical design of SPWTF prevents containers of wastewater from being transferred to the facility. Transfer stations or similar areas are not present at SPWTF.

\subsection{EEMTF and CMTF}

Wastewater from significant sources other than building sumps is not accepted for treatment without prior approval of TDEC, Division of Water Pollution Control, personnel. However, wastewater not specified in the procedures may be temporarily accepted on a case-by-case basis, with memorandums of understanding written to specify acceptance criteria, analytical parameters, and sampling frequency. Memorandums of understandings will be used when procedure revisions are impractical. Transfer stations or similar areas are not present at the EEMTF or CMTF. 


\subsection{SAMPLING}

\subsection{WETF, WTF, and CPCF}

All waste sampling is done following the SW846 protocol to ensure precision and accuracy. In the laboratory, the samples are analyzed using SW846 or comparable Environmental Protection Agency methods. Wastes, except some purged well waters with historical data demonstrating that the water is well within acceptance standards, are typically analyzed for the following constituents:

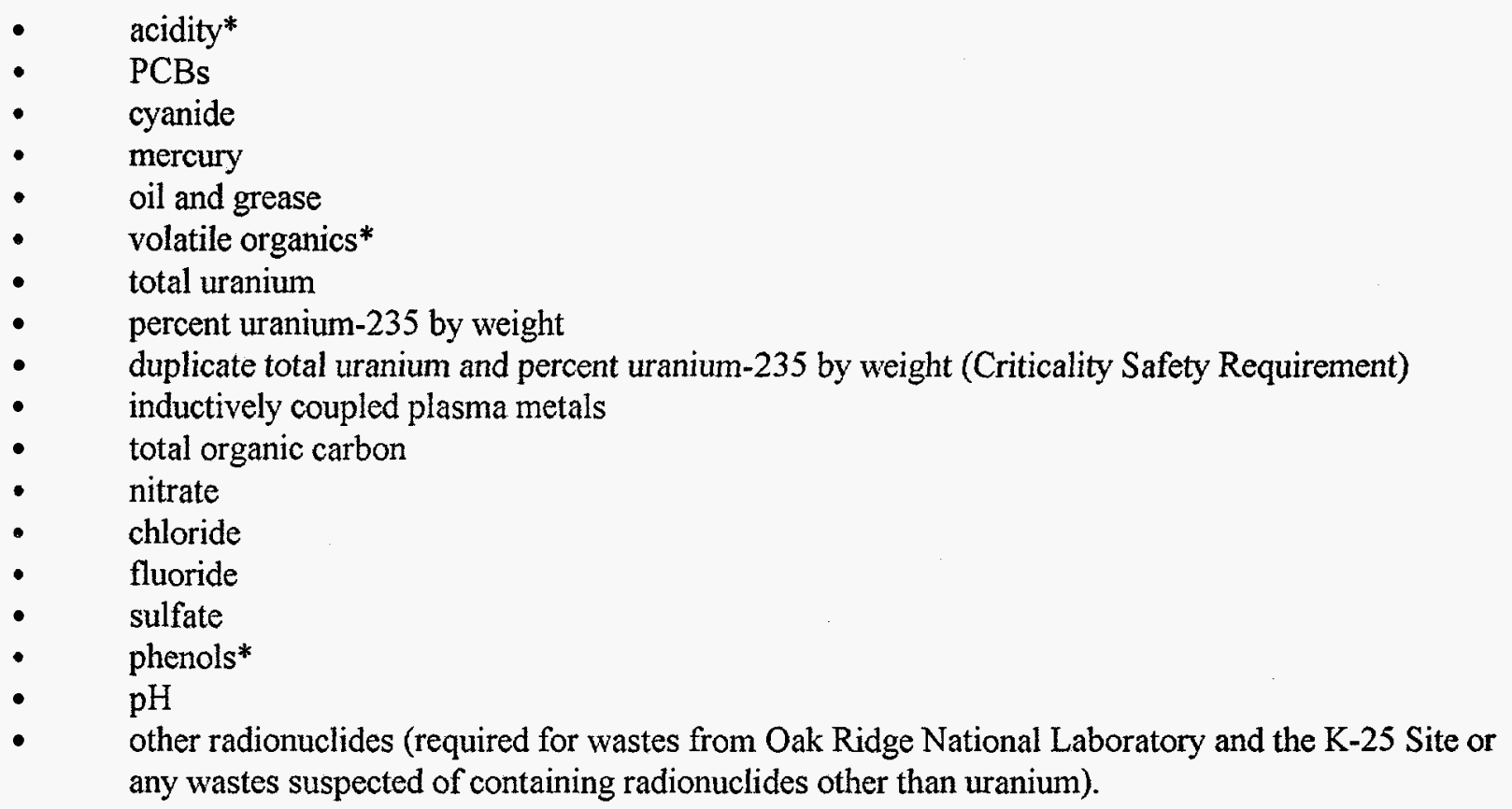

* Not routinely required for accumulated storm water from secondary containment which has failed the screening criteria for discharge to EFPC.

Exempt from these sampling requirements are some small quantity shipments, usually 55 gallons or less, which are bulked and neutralized in a mixing tank before sampling. Also, the Waste Certification Program gives generators a mechanism for using validated process knowledge in lieu of some sampling requirements. Any exceptions to sampling requirements are made with the concurrence of the WTC.

\subsection{GWTF}

Sampling, acceptance, and notification requirements are detailed in a memorandum of understanding for shipments from the K-25 Site. Monthly and quarterly sampling results are sent to the GWTF Facility Engineer for review. While each shipment or unit of water to these facilities may not be analyzed, the wastestreams are consistent, and a thorough characterization of the source water has been performed.

\subsection{SPWTF, EEMTF, and CMTF}

Because the wastestreams entering SPWTF, EEMTF, and CMTF are consistent and directly piped to the facility (except sump water from Building 9204-4), wastewater is not sampled prior to acceptance. 


\subsection{DATA REVIEW AND TREATMENT FACILITY ASSIGNMENT}

\subsection{WETF, WTF, and CPCF}

The WTC reviews the analytical data for all wastewater. Acceptance and assignment to a treatment facility are determined by comparing analytical data with the waste evaluation criteria for the CPCF (Y50-41-WP-08.02), WETF (Y50-41-WT-09.21), and WTF (Y50-41-WT-03.21). Deviations to these guidelines, except those firm restrictions stated above, may be approved on a case-by-case basis if jar testing indicates that the wastewater can be treated successfully.

Based on analytical results and container size, wastes are routed by the WTC to one of four places: the CPCF, 500,000 -gallon tanks at the WTF, or the mixing tank (Slurry Box) at WTF. As stated above, small quantity containers of 55 gallons or less are routinely sent to the Slurry Box at WTF for bulking, neutralization, and sampling. Wastewater containing nitrates must ultimately be denitrified at WTF. If nitrate solutions require metals removal or neutralization prior to disposal at WTF, then the wastewater must first undergo pretreatment at either the CPCF or WETF. Wastewater with nitrates less than $100 \mathrm{ppm}$ and total organic carbon less than $2,000 \mathrm{ppm}$ is routinely sent to CPCF for treatment.

\subsection{SPWTF}

Not applicable to operations at SPWTF.

\subsection{GWTF, EEMTF, and CMTF}

Not applicable to operations at the GWTF, EEMTF, and CMTF; however, wastewater not specified in the procedures may be temporarily accepted on a case-by-case basis, with memorandums of understanding written to specify acceptance criteria, analytical parameters, and sampling frequency. Memorandums of understandings will be used when procedure revisions are impractical.

\subsection{RECORD KEEPING AND DOCUMENTATION}

All documentation will be kept for a minimum of 3 years and will be made available to TDEC, Division of Water Pollution Control, personnel within 15 days if requested.

\subsection{WETF, WTF, and CPCF}

Waste Item Description forms (UCN-2109 forms) are maintained by Waste Management Organization personnel for each wastestream received at the WETF, WTF, and CPCF. These forms include information such as description, quantity, source, analytical data, and designation of the treatment facility.

\subsection{GWTF and LSF}

The GWTF Facility Engineer maintains records and documentation for wastewater received at the GWTF and LSF. 


\subsection{SPWTF}

The Utilities Department staff maintains operating logs and records for the SPWTF.

\subsection{EEMTF and CMTF}

Records and documentation for wastewater received at the EEMTF and CMTF are maintained by Waste Management Organization personnel.

\subsection{TREATMENT SYSTEM CHANGES}

Significant wastestreams, other than those described above, will not be added to the existing treatment systems without prior notification and approval by TDEC, Division of Water Pollution Control, personnel. Significant wastestreams will be added to the treatment systems only after review for treatability as described in the procedures above or by the Facility Engineer. If significant revisions are made to the procedures referenced above, a notification will be made to TDEC, Division of Water Pollution Control, personnel.

\subsection{PREVENTIVE MAINTENANCE PROGRAMS}

\subsection{WETF, CPCF, and GWTF}

The WETF, CPCF, and GWTF are operated in batch treatment mode. Failure of the treatment system should not cause untreated wastewater to be discharged; therefore, backup and auxiliary systems are not necessary to maintain compliance with the NPDES permit. There are no auxiliary or backup power systems at the WETF except the criticality accident alarm. Discharges from the WETF occur only when the Effluent Polishing System (EPS) is operating. The facility is manned when the EPS is operating so that, if there is a power failure, operators follow procedures to shut down the EPS immediately until power is restored. In the event of a major mechanical failure, the system is shut down to make the repair or temporary modification. The LSF has a diesel generator that provides emergency power to the pumps and instruments at the lift station and collection points, and to the discharge pump from the LSF oil/water separator. The backup power source prevents overflows of wastewater from the lift station to Tributary 8 during a power outage. The generator is tested once per month, and records of these tests are maintained by Waste Management Organization personnel. If there is an equipment failure or loss of required utilities at the LSF, the operation is shut down immediately with the following exception: leachate collection into the lift station and subsequent transfer of the water to the LSF continues automatically (on emergency power if necessary). If a high-level alarm is received for the water level in the lift station, the steps in "LSF - Alarm Response Procedure" (Y50-41-WT-.01.17) are followed to prevent overflows.

\subsection{SPWTF, EEMTF, and CMTF}

Backup and auxiliary systems are not in place at SPWTF, EEMTF, and CMTF. The discharges can be controlled; therefore, accidental discharges of nontreated wastewater should not occur. Secondary power sources do not exist; however, the facilities cannot discharge without power to operate the discharge pumps. 


\subsection{BUILDING DRAINS}

As part of the wastewater control program, Y-12 Plant personnel will maintain and update the site survey of buildings and area drains. Any survey documentation will be updated to reflect changes such as the addition of drains to a building or the removal of drains from service. The drain survey documentation will also be updated to include additional buildings or process areas constructed or put in service that are connected to either the storm sewer or sewage collection system. 
Distribution:

S. A. Adams

K. R. Crow

J. T. Foust

C. C. Hill

A. K. Lee, DOE-OSTI (2), 9983-30, MS-8175

D. M. Maguire

W. G. McMillan, DOE-ORO

N. G. McRae

S. D. Morris, DOE-ORO

W. P. Ragain

B. E. Skaggs

T. C. Surratt

L. O. Vaughan

P. J. Wempner

A. R. Winningham

Y-12 Central Files

File-EMD-RC 